\title{
From 'welfare' to 'workfare', and back again? Social insecurity and the changing role of the state
}

\author{
Christopher Deeming and Ron Johnston
}

\section{Introduction}

All of the advanced societies must provide their citizens with protection against risk in order to secure continued economic and political stability. In Britain, we have seen major welfare reforms and shifts in public opinion towards the role of the state in providing social security, while in other advanced nations support for social protection still commands popular support. In this chapter we consider theories of the policymaking processes (Box 1) and changing public attitudes towards unemployment protection in the 'welfare' state, drawing on national and comparative social survey data spanning more than three decades for the analyses.

\section{Box 1. Theories of public opinion and policy-making}

Policy 'feedback'

Social and political institutions and governmental policies provide feedback effects to voters (Pierson 1993), which helps them to navigate their world. Once in place, policies have 'increasing returns', leading to 'path dependence' in policy (Pierson 2000). Policy legacies matter. If change occurs, it intends to be incremental - which helps explain 'incrementalism' in policy-making.

Institutional 'logics'

Welfare institutions and welfare attitudes are inextricably linked, implying that welfare states have a tendency to produce and reproduce their own legitimacy (Larsen 2006). This is made particularly evident from a comparative perspective. For instance, there is high support for social rights and welfare institutions in Nordic countries like Sweden compared to liberal countries like the USA.

'Thermostat' model

The 'thermostatic model' (Wlezien 1995) suggests if trends in public opinion change, i.e. the 'temperature' set by the 'thermostat' goes up or down, the government will respond to that change and shift policy position again. The public sends signals to policymakers in the form of preferences for 'more' or 'less' spending, as it reacts to changes in policy. The public adjusts or changes its preferences, wants less spending after a period when welfare spending has increased, and vice versa.

'Weather vane' model

This model suggests there is scope for political leadership in policy-making (Hills 2002, Curtice 2010). If the public are persuaded of the merits of governmental actions it may align its views with the direction set by policymakers.

\section{From the KWS to the SWS}

In Britain, the 'Keynesian Welfare State' (KWS) was constructed over the first half of the 20th century, consolidated by the Labour government - elected in 1945 - which implemented 
the principles and mechanisms set out in the 1942 Beveridge Report designed to slay the five 'giant evils' - squalor, want, disease, ignorance and idleness. Its nature was widely welcomed across society and its parameters were largely accepted and kept in place by subsequent Conservative governments, along with the policy goal of 'full employment'. By the 1980s however, the KWS came under increasing criticism from those who saw the problem of 'moral hazard' in the 'unconditional welfare system' amid growing concerns over 'long-term unemployment' (Layard et al. 1991: 62). Changes in the economy and pattern of employment meant that 'structural' unemployment was now more of a risk, compared to the ups and downs of 'cyclical' unemployment in the industrial period.

Under post-industrial pressures an alternative 'Schumpeterian Workfare State' (SWS) was promoted by Conservative politicians (Jessop 1995, Peck 2001). The state's main role of 'demand management' was now replaced by 'supply management' designed to promote labour market flexibility. Social policy became more subordinate to the needs of the market with the Thatcher government intent on rolling back the frontiers of the state in the changing context of 'permanent austerity' (Pierson 2001). Unemployment benefits had been a stopgap provision for workers between jobs, to be eligible to receive these benefits claimants had to register for work. In the SWS conditionality was intensified. We find 'policy transfer' from the USA, as Thatcher turned to the Reagan administration for ready-made 'welfare-to-work' solutions like 'Job Clubs' and 'Employment Training Schemes' (Dolowitz 1998). 'Jobseeker's Allowance' (JSA) replaced 'Unemployment Benefit' and 'Income Support' (Jobseekers Act 1995). Claimants became 'jobseekers' (actively seeking work), and 'work first' rules encouraged welfare beneficiaries to accept any job that was offered. An Americanstyle 'workfare' (mandatory work-for-the-dole) programme was introduced in Britain for the first time in 1996 targeting the long-term unemployed. There was more contracting-out of unemployment services (e.g. training) to private and voluntary operators. There was a real sea change in government policy and rhetoric.

The British public did not appear to respond to this change in government tone and ethos, at least not initially (Pierson 1994: 146-9). While Margaret Thatcher had won two landslide general election victories in 1983 and 1987 she did not create an enduring rightwards realignment in public opinion regarding welfare reform. The electorate opposed many of the policy initiatives, leading Crewe to conclude that 'much of Thatcherism will die with Thatcher' (Crewe 1989: 250). 
Although reforms under Thatcher's third term (1987-1990) and the administrations of John Major (1990-1997) had created the foundations for 'workfare' in Britain, the fully integrated and well-defined 'welfare-to-work' regime was secured by Labour, in Tony Blair's first term (1997-2001). Known as the 'New Deal' programmes, evocative of Franklin Roosevelt's 'New Deal' public works projects, they owed a great deal to Bill Clinton's welfare reforms in the USA (King and Wickham-Jones 1999). The 'New Deal' programmes for lone parents (1997), young people (1998) and the long-term unemployed (1998) involved work-focused interviews with personal advisors were designed to move more welfare beneficiaries into paid employment. Labour was drawing on American-style social policy. Blair had prioritised health and education and promised 'work for those who can' in order to reduce the pressure on social security spending. Labour invested in early childhood education and care services for working parents, introduced 'tax credits' and the National Minimum Wage (NMW) in 1999 to help ensure that work always pays more than benefits. Under Thatcher the shift towards a workfare regime was in the margins of employment policies; for Blair (1997-2007) and New Labour it became the "ideological cornerstone" of policy development (Peck 2001: 262). 'Workfarist' principles, as Peck (2001: 9-16) suggests, diverge significantly from those of 'welfarism'. The ideological foundations of welfare structures are statist, redistributional with needs-based entitlement and citizenship rights, in contrast to market-oriented and employability based workfare, which is largely about duties and obligations, reciprocity, selfhelp and the enforcement of work and work values in mandatory work programmes. Thus, Glennerster (2001: 385) concluded that in retrospect Blair's 'Third Way' approach to social policy would be seen as a decisive shift away from the previous Labour Party position: as "a move away from an all-inclusive universal welfare state - never achieved in practice but always a dream" - to what was termed 'selective universalism' in British social policy (Hills 2017). However, taking the British public with the new strategy would not be easy according to Glennerster (2001: 402).

\section{How has the public reacted to workfare policies?}

In this section we consider changing public opinion and to what extent? Which groups within society changed most, when, where and why - did politicians lead or follow public opinion? To answer those questions we assembled relevant BSA survey data (Box 2) and welfare 
attitudinal questions to chart the changes in public opinion across social groups, time and place.

\section{Box 2. Surveys of public opinion \\ British Social Attitudes (BSA)}

The BSA is the best available source of high quality data on public attitudes in Britain. Every year over 3,000 people participate in this survey. Participants are selected using random probability sampling that ensures the results are representative of the British population http://www.bsa.natcen.ac.uk/. Material from the BSA (e.g. NatCen Social Research 2017) is made available by the UK Data Service http://data-archive.ac.uk/ where this study is registered (Usage 73549: Welfare Attitudes).

\section{International Social Survey Programme (ISSP)}

Established in 1984, the ISSP is a programme of cross-national collaboration providing crossnational and cross-cultural perspectives on key research topics in the social sciences http://www.issp.org/about-issp/. A repeated cross-sectional survey design is used along with sampling procedures to ensure views are nationally representative in the participating countries. The Role of Government (RoG) module analysed here comprises four surveys conducted in 1985, 1990, 1996, 2006 and 2016 (ISSP Research Group (2008, 2018). Material from the RoG is made available by the ISSP, from the GESIS-Leibniz Institute for the Social Sciences website https://www.gesis.org/en/en/home/.

The BSA survey evidence points to fundamental shifts in public views on welfare state provision for unemployed people over the past three decades. In Figure 1, we find - throughout much of the 1980s and early-1990s - a widespread belief that unemployment benefit was set at derisory levels, causing hardship for claimants. In 1983, for example, $46 \%$ of the British population said that unemployment benefit was "too low" and "caused hardship". By 1993, that figure had risen to $55 \%$. 
Figure 1. Changing British attitudes towards unemployment benefits

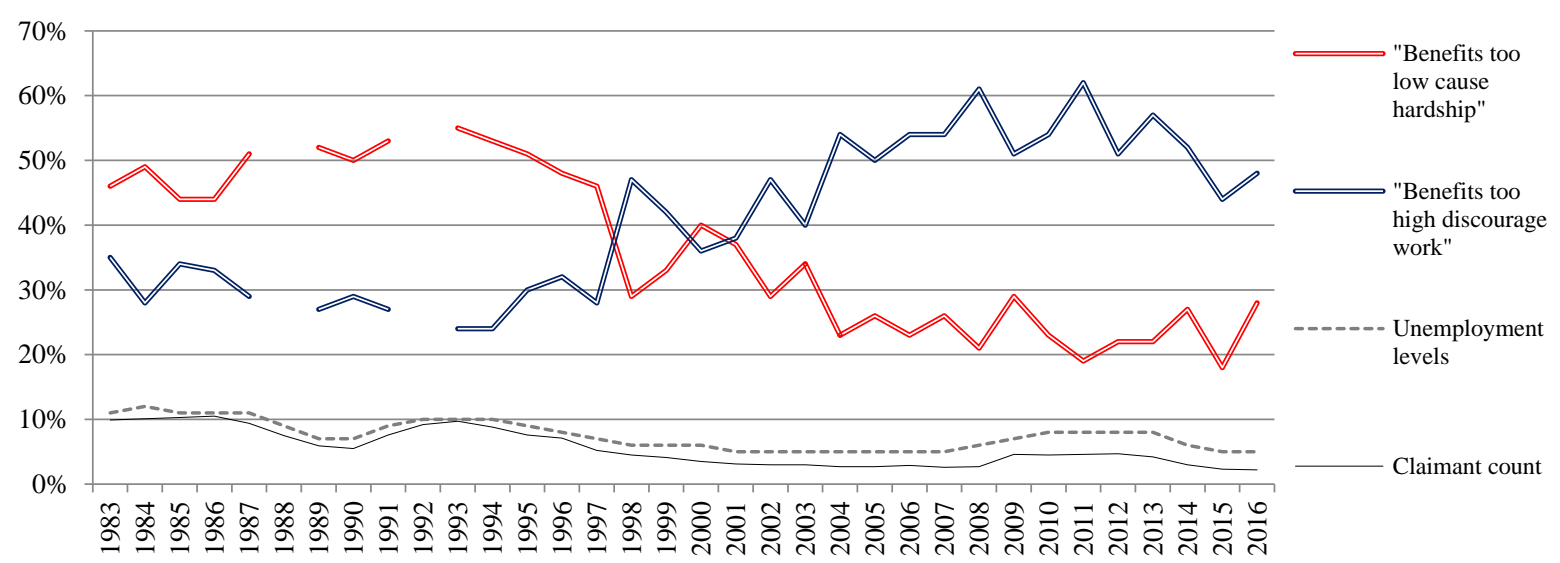

Sources:

Attitudinal data: BSA 1983-2016.

Claimant count data, here the number of people claiming benefit principally for the reason of being unemployed shown as a percentage of workforce jobs: ONS Claimant Count and Vacancies time series dataset (release 12 June 2018).

Unemployment data: International Monetary Fund's World Economic Outlook Database, October 2017 Edition.

At the start of the 21 st century however, a distinct attitudinal shift begins to emerge, public attitudes towards unemployment benefit hardens (Figure 1) amid growing 'distrust' in the use of the welfare system (Figure 2). British social attitudes now follow the logic of Labour policy. Labour supporters and working-class voters, in particular, accept Labour's workfare line (Deeming 2015).

Figure 2. Proportion of the British public reporting that most unemployed people could find a job if they really wanted

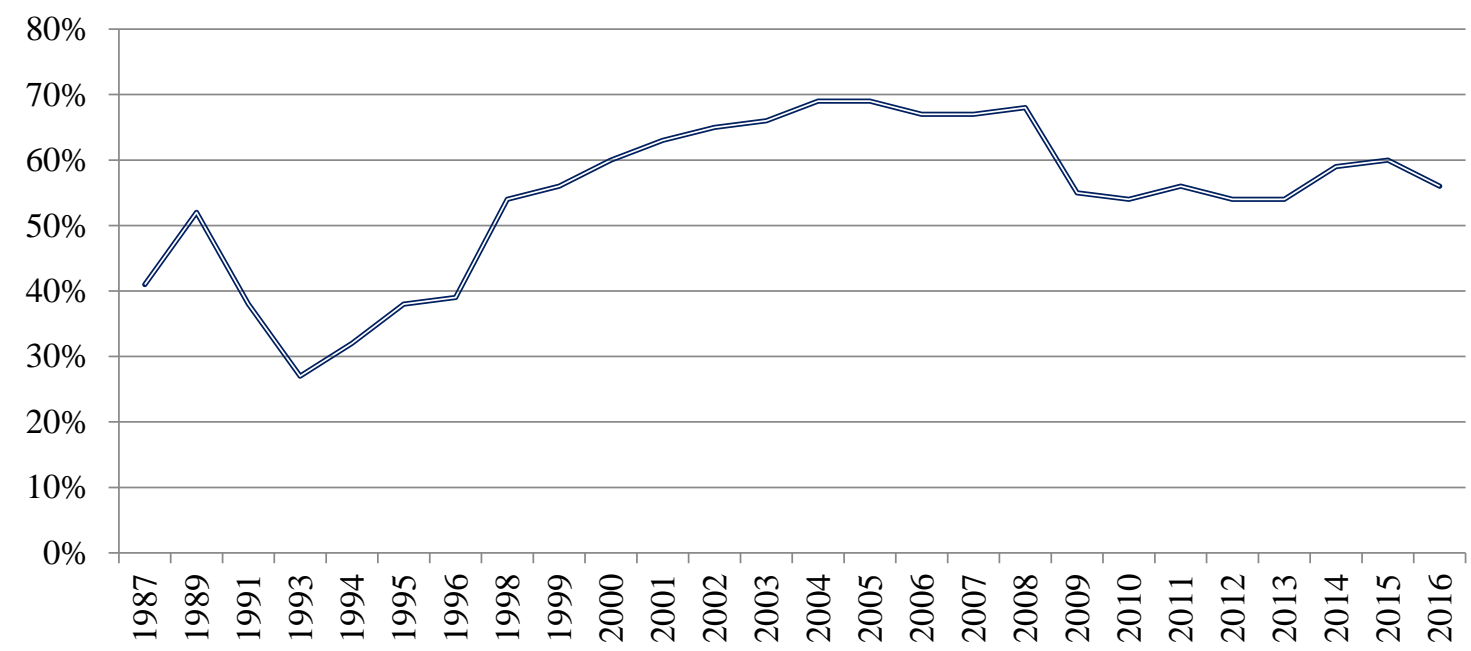

Source: BSA 1987-2016. 
By 2015, and with the Conservative Party's punitive workfare programme now in place, only $18 \%$ of the British population said unemployment benefit was "too low" and "caused hardship". The government's policy agenda was reinforced by a very negative portrayal of benefit claimants in the mainstream media, with the discourse of 'strivers' vs. 'scroungers', and the narrative of 'welfare dependency' (Hills 2017). The political rhetoric on welfare reform became much more aggressive at this time dividing electorates between 'winners' and 'losers', driven by a policy and vote-seeking logic.

Today, most people in Britain claim that unemployment benefits are "too high" and "discourage work" despite the fact that benefit levels have remained constant in real terms over the past three decades (Deeming 2015: Figure 2, p.869; see also Geiger (2017) on benefit 'myths'). While there are notable and expected fluctuations in the attitudinal data reflecting downturns in the economy, the 2007/8 Global Financial Crisis (GFC) for example (the 'deservingness' of unemployed claimants is sensitive to the unemployment rate, Oorschot 2006), there is also evidence in the most recent survey rounds to suggest attitudes towards unemployment benefits are softening (Figure 1). The extent to which this represents a 'thermostat' effect, as the public now begins to react against 'austerity' and Tory cuts, or rather a 'weather vane' effect as the public are persuaded by political leadership and the policy positions adopted by the Scottish National Party (SNP) and Labour Party. Labour's 2017 Election Manifesto, for example, made multiple references to ending punitive benefit sanctions while social security in Scotland is now set to become a basic human right (Social Security (Scotland) Act 2018). Scottish people are often said to be more pro-welfare and left-wing than people in England, and the BSA data shown in Figure 3 tends to support this view. However, there was a fundamental change in Scottish social attitudes towards benefit claimants in the late-1990s, during the implementation Labour's welfare-to-work programme. Tony Blair clearly led public opinion, claiming that welfare should be "a hand-up, not a hand-out". 
Figure 3. Agreement that benefits for unemployed people are too low and cause hardship, Scotland and England, 1983-2016

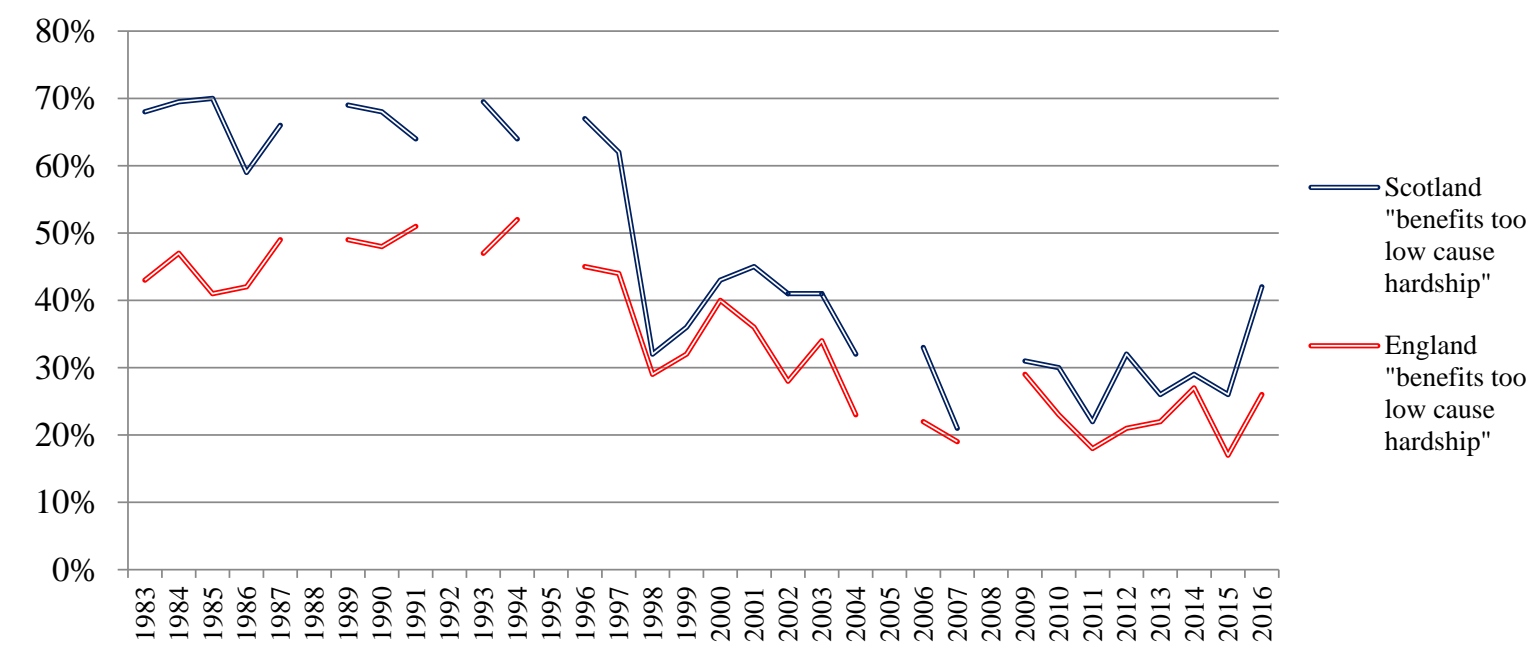

Source: BSA 1983-2016 and Scottish Social Attitudes (SSA) for 1999-2003, 2006, 2009, 2010 and 2013.

Did this change in social attitudes occur equally across society? To address that question, we fitted logistic regression models (see Deeming and Johnston 2018: 403, Table 1) with the dependent variables being the responses to the BSA questions relating to welfare benefits for unemployed people. The BSA data suggest those aged 25-64 were significantly more likely to be pro-welfare than either young adults or older persons; those who were of a religious disposition were significantly more likely to be pro-workfare than those who were not religious, as were those with lower or no qualifications compared to those with degrees. Unemployed workers and trades union members were more likely to be pro-welfare state compared to those in employment and non-union members.

What about spatial divides? The results for regions show that pro-workfare opinions were more common (after controlling for all of the other variables) in England's southern regions compared to northern English regions. These geographical variations were patterned commensurate with the well-known North-South divide in the British economy, society and polity (Johnston et al. 2005, 2018). For instance, whereas respondents in the northern English regions (Northwest, and Yorkshire and the Humber) and in Scotland were 20-30\% more likely to be more pro-workfare than pro-welfare compared to those in the Northeast, those in England's southern regions - the economically more-advantaged areas in recent decades were above $50 \%$ more likely to be more pro-workfare. More detailed spatial analysis with the BSA data also reveals an increase in pro-workfare support and arguably anti-welfare state 
sentiments over time. We also found British people were more pro-welfare state during Major's premiership than they were under Thatcher's. There was then a substantial increase during the next two premierships - with pro-workfare levels being between 1.7 and 3.0 times larger under Blair and then Brown respectively as they were under Thatcher, with that difference either levelling-off under Cameron. British public attitudes follow the logic of government policy. Labour supporters, in particular, accepted the workfare line promoted by the Blair government.

\section{Comparative attitudes towards social security}

What about the British experience in a comparative context? Here we consider cross-national attitudes towards the role of government in providing social security for unemployed people using the RoG survey modules (Box 2). The data suggest that solidarity emerges most strongly in the Continental and Northern European countries (Table 1). In Nordic welfare states, for example, less than one-fifth of the public responding to the 2016 survey claim it should not be the government's responsibility to "provide a decent standard of living for unemployed people". Only about $10 \%$ did so in Norway. In the Bismarckian welfare states, we find less solidarity for unemployed workers compared to the Nordics (an effect of the contributory social insurance model). However, no more than one-third of citizens in France and Germany reject governmental action to help protect workers. By contrast, in the 'liberal' or arguably 'neoliberal' countries, the public is much more divided. One-half support the merits of collective social security provision to safeguard and protect citizens against labour market related risk, while the other half now favours self-insurance or some other form of individual adaptation to labour market flexibility and risk. In the USA, solidarity with unemployed workers is found to be at its lowest in the study sample; here workfare policies have a long history having been pioneered in the 1960s and 1970s compared to Britain, Australia and New Zealand where workfare arrived later, in the 1980s and 1990s, learning lessons from the USA. 
Table 1. Proportion reporting government should provide a decent living standard for unemployed people

\begin{tabular}{|c|c|c|c|c|c|}
\hline & $\begin{array}{c}1985 \\
\%\end{array}$ & $\begin{array}{c}1990 \\
\%\end{array}$ & $\begin{array}{c}1996 \\
\%\end{array}$ & $\begin{array}{c}2006 \\
\%\end{array}$ & $\begin{array}{c}2016 \\
\%\end{array}$ \\
\hline Liberal welfare states & & & & & \\
\hline Australia & 59 & 56 & 65 & 57 & - \\
\hline New Zealand & - & - & 64 & 49 & 62 \\
\hline UK & 86 & 80 & 79 & 57 & 60 \\
\hline USA & 50 & 53 & 48 & 52 & 57 \\
\hline Mean & 65 & 63 & 64 & 54 & 60 \\
\hline Bismarckian welfare states & & & & & \\
\hline France & - & - & 81 & 70 & 68 \\
\hline Germany & 85 & 83 & 84 & 71 & 72 \\
\hline Mean & - & - & 83 & 71 & 70 \\
\hline Nordic welfare states & & & & & \\
\hline Norway & - & 91 & 93 & 89 & 89 \\
\hline Sweden & - & - & 90 & 83 & 76 \\
\hline Mean & - & - & 92 & 86 & 83 \\
\hline
\end{tabular}

Source: ISSP RoG I-V.

In the liberal welfare states as a whole, we also find most people are sceptical about the "government's responsibility to provide a job for everyone who wants one" (Table 2). In the USA, negative attitudes have been fairly constant over all survey waves. In this exemplary liberal regime, such findings may not surprise given the dominant laissez-faire ideology and weak human capital enhancement programmes for low-skilled workers. The strongest levels of support for the right to work are found in the coordinated market economies of Continental and Northern Europe, where full employment and active labour market programmes have been favoured from as early as the 1950s. The universalistic Nordic model of welfare has entirely depended on employment maximization, and the state therefore played a key role in securing this goal. Nearly three-quarters of the population in Norway still claim that it is the government's responsibility to ensure everyone has a job compared to just over a third in the USA. In Sweden, however, there have been dramatic falls in support for governmental action to ensure jobs for all. 
Table 2. Proportion reporting government should provide jobs for everyone

\begin{tabular}{|c|c|c|c|c|c|}
\hline & $\begin{array}{c}1985 \\
\%\end{array}$ & $\begin{array}{c}1990 \\
\%\end{array}$ & $\begin{array}{c}1996 \\
\%\end{array}$ & $\begin{array}{c}2006 \\
\%\end{array}$ & $\begin{array}{c}2016 \\
\%\end{array}$ \\
\hline Liberal welfare states & & & & & \\
\hline Australia & 53 & 42 & 44 & 43 & - \\
\hline New Zealand & - & - & 55 & 37 & 42 \\
\hline UK & 72 & 63 & 69 & 56 & 51 \\
\hline USA & 35 & 44 & 39 & 40 & 36 \\
\hline Mean & 53 & 50 & 52 & 44 & 43 \\
\hline Bismarckian welfare states & & & & & \\
\hline France & - & - & 69 & 62 & 68 \\
\hline Germany & 82 & 80 & 80 & 68 & 63 \\
\hline Mean & - & - & 75 & 65 & 66 \\
\hline Nordic welfare states & & & & & \\
\hline Norway & - & 84 & 81 & 79 & 72 \\
\hline Sweden & - & - & 65 & 59 & 49 \\
\hline Mean & - & - & 73 & 69 & 61 \\
\hline
\end{tabular}

The findings suggest the institutional welfare regime logic holds, at least to a degree, and certainly in the service areas for which they were originally designed - social security for working aged citizens (although the regime pattern is less evident in other policy areas such as health and pensions, cf. Deeming 2017). In general, support for less stratifying forms of social policy emerges most strongly in the Nordic countries, while unemployed people are mostly regarded as underserving across the liberal welfare states. However, attitudes do appear to have softened here in the recent survey round, a likely 'thermostatic' response to recent austerity measures. There continues to be a high degree of solidarity in the Northern and Continental European countries shown in the tables above - institutions and social policies have 'feedback' effects as Pierson (1993, 1994: Chapter 2) righty stresses - but the effects of reform, increased benefit conditionality and stricter activation, is evident in the declining support for comprehensive state welfare.

\section{Conclusions}

A number of conclusions emerge. The first is that British citizens became substantially more 'workfarist' and, implicitly, less 'welfare statist' - or, in other terminologies, more 'rightwing' or 'neoliberal' - over the last three decades, especially during the Labour administrations led by Blair and Brown. Secondly, this rightward move not only involved most groups within society (defined by age, trade union membership, occupational class); in addition the attitudinal gaps within each of those groups narrowed during the Blair-Brown 
years, as did the gap between the regions. The country had become more homogeneously proworkfare than it had been during the Thatcher and, especially, Major administrations.

Here we may draw attention to the role of political discourse and the actions of political parties in shaping public attitudes in the policy process. Public preferences here are shown to follow rather than precede policies. New Labour supporters followed the logic of governmental policy and accepted the 'workfare' line promoted by Blair. Our findings therefore help to shed new light on relations between party policies, popular attitudes and their political impact. As governments in Britain have moved right over the past three decades, public attitudes have not tacked left, at least not until relatively recently. Only now do we begin to observe signs of a shift away from workfare and the system of benefit sanctions.

The UK Westminster government has very largely adopted the American model regarding the role of welfare, and in that way moved away from the dominant position of most EU countries and Scotland. Under the SNP, Scotland has rejected the workfare model, social security will now be a basic human right. Scotland is also planning experiments with Universal Basic Income (UBI). There are also signs that Labour is also distancing itself away from workfare and the sanctions regime, in favour of social policy once again.

\section{Acknowledgments}

We are grateful to the editors, referees and Howard Glennerster for critical comments.

\section{References}

Crewe, I. (1989) Values: the crusade that failed, in D. Kavanagh and A. Seldon (eds) The Thatcher Effect: A Decade of Change, Oxford: Clarendon Press, 239-250.

Curtice, J. (2010) Thermostat or weather vane? Public reactions to spending and redistribution under New Labour, in A. Park, J. Curtice, K. Thomson, M. Phillips, E. Clery and S. Butt (eds) British Social Attitudes 26th Report, London: Sage, 19-38.

Deeming, C. (2015) Foundations of the workfare state - reflections on the political transformation of the welfare state in Britain, Social Policy \& Administration 49(7): 862886.

Deeming, C. (2018) The politics of (fractured) solidarity: a cross-national analysis of the class bases of the welfare state, Social Policy \& Administration 52(5): 1106-1125.

Deeming, C. and R. J. Johnston (2018) Coming together in a rightward direction: post-1980s changing attitudes to the British welfare state, Quality \& Quantity 52(1): 395-413.

Dolowitz, D. P. (1998) Learning from America: Policy Transfer and the Development of the British Workfare State, Brighton: Sussex Academic Press.

Geiger, B. B. (2017) Benefit 'myths'? The accuracy and inaccuracy of public beliefs about the benefits system, Social Policy \& Administration 52(5) 998-1018. 
Glennerster, H. (2001) Social policy, in A. Seldon (ed.) The Blair Effect: the Blair Government 1997-2001, London: Little, Brown, 384-403.

Hills, J. (2002) Following or leading public opinion? Social security policy and public attitudes since 1997, Fiscal Studies 23(4): 539-558.

Hills, J. (2017) Good Times, Bad Times: the Welfare Myth of Them and Us, Revised Edition, Bristol: Policy Press.

ISSP Research Group (2008) International Social Survey Programme: Role of Government IIV - ISSP 1985-1990-1996-2006, Cologne: GESIS Data Archive, ZA4747 Data file Version 1.0.0, DOI: https://doi.org/10.4232/ 1.4747.

ISSP Research Group (2018) International Social Survey Programme: Role of Government V - ISSP 2016, Cologne: GESIS Data Archive, ZA6900 Data file Version 1.0.0, DOI:10.4232/1.12994.

Jessop (1995) Towards a Schumpeterian workfare regime in Britain? Reflections on regulation, governance, and welfare state, Environment and Planning A: Economy and Space 27(10): 1613-1626.

Johnston, R. J., C. J. Pattie and D. J. Rossiter (2005) The election results in the UK regions, in P. Norris and C. Wliezen (eds) Britain Votes 2005, Oxford: Oxford University Press, 130-145.

Johnston, R. J., D. Manley, C. Pattie and K. Jones (2018) Geographies of Brexit and its Aftermath: Voting in England at the 2016 Referendum and the 2017 General Election, Space and Polity 22(2): 162-187.

King, D. and M. Wickham-Jones (1999) Bridging the Atlantic: the Democratic (Party) origins of welfare to work, in M. Powell (ed.) New Labour, New Welfare State: the 'Third Way' in British Social Policy, Bristol: Policy Press, 257-280.

Larsen, C. A. (2006) The Institutional Logic of Welfare Attitudes: How Welfare Regimes Influence Public Support, Aldershot: Ashgate.

Layard, R., Nickell, S. and R. Jackman (1991) Unemployment: Macroeconomic Performance and the Labour Market, Oxford: Oxford University Press.

NatCen Social Research (2017) British Social Attitudes Survey, 1983-2016 [data collection], UK Data Service, SN: 8252, http://doi.org/10.5255/UKDA-SN-8252-1.

Oorschot, W. van (2006) Making the difference in social Europe: deservingness perceptions among citizens of European welfare states, Journal of European Social Policy 16(1): 2342.

Peck, J. (2001) Workfare States, New York and London: Guilford Press.

Pierson, P. (1993). When effect becomes cause: policy feedback and political change, World Politics 45(4): 595-628.

Pierson, P. (1994) Dismantling the Welfare State: Reagan, Thatcher, and the Politics of Retrenchment, Cambridge University Press.

Pierson, P. (2000) The limits of design: explaining institutional origins and change, Governance 13(4): 475-499.

Pierson, P. (2001) The New Politics of the Welfare State, Oxford: Oxford University Press. 
Wlezien, C. (1995) The public as thermostat: dynamics of preferences for spending, American Journal of Political Science 39(4): 981-1000. 